\title{
Are MSMEs Still Interesting? A Descriptive Analysis on Growth, Workforce, and Export of Indonesian MSMEs 2010-2018
}

\author{
S. Martono ${ }^{1}$, Lennora Putit ${ }^{2}$, Arief Yulianto ${ }^{3}$, Siti Ridloah ${ }^{4}$ \\ \{ariefyulianto@mail.unnes.ac.id ${ }^{3}$ \} \\ Universitas Negeri Semarang, Indonesia ${ }^{1,3,4}$ \\ Universiti Teknologi Mara, Malaysia ${ }^{2}$
}

\begin{abstract}
This study aims to describe year on year about the number of MSME business units, the number of MSME workforce, and the total number of MSME exports in the period of 2010-2018. Secondary data used in this study came from the Ministry of Cooperatives and SMEs in the period 2010-2018 with interval scale and pooled data. The results of the study were in the period of 2010-2018: the number of MSMEs increased by $21.06 \%$; the number of large businesses increased by $18.70 \%$; the proportion of the number of MSMEs compared to large businesses increased from $99.9911 \%$ to $99.9914 \%$; the average number of workers in large businesses has increased from 576 people to 652 people; the ability to absorb labor at MSMEs has increased from 316 to 357 times greater than large businesses; the number of MSME exports increased by 36.6\%; the number of exports of large businesses decreased and the ratio of the number of MSME exports compared to large businesses increased from $21 \%$ to $150 \%$. The conclusion of this study is the number of MSMEs and the ability to absorb labor has increased from the period 2010-2018. However, the number of non-oil exports have fluctuated from the period 2010-2018. Therefore, MSMEs facilitation policy from the government is needed so that MSMEs are able to access product sales overseas.
\end{abstract}

Keywords: Audit Quality, Audit Committee, KAP Size, Auditor Specialization.

\section{Introduction}

The understanding of MSMEs according to Law 20/2008 on Micro, Small and Medium Enterprises sets limits on the MSME criteria [1]. The criteria for Micro Business are as follows: (a) Has a net asset of no more than Rp 50,000,000 (fifty million rupiah) excluding land and buildings where the business is located; or (b) Has annual sales results of at most Rp.300,000,000.00 (three hundred million rupiah). Whereas, Small Business Criteria are as follows: (a) Has a net worth of more than Rp.50,000,000.00 (fifty million rupiah) up to a maximum of Rp500,000,000.00 (five hundred million rupiah) excluding land and buildings where the business is located; or (b) Has annual sales results of more than Rp.300,000,000.00 (three hundred million rupiah) up to a maximum of Rp2,500,000,000.00 (two billion five hundred million rupiah). The criteria for Medium Enterprises are as follows: (a) Has a net asset of more than Rp. 500,000,000.00 (five hundred million rupiah) up to a maximum of Rp $10,000,000,000.00$ (ten billion rupiah) excluding land and buildings where the business is 
located; or (b) Has annual sales results of more than Rp2,500,000,000.00 (two billion five hundred million rupiah) up to a maximum of Rp50,000,000,000.00 (fifty billion rupiah).

The potential of MSMEs in Indonesia both in reducing unemployment and accelerating economic growth, but there are still many obstacles in the optimal funding policy, so that the competitiveness of large businesses remains weak. Riyanto et al. [2] research with OLS model shows that MSMEs in Manokwari are able to absorb more workers than large businesses, but are constrained in the matter of funding decisions. It is recommended not to increase debt in funding decisions even though the fixed assets can be used as collateral. Furthermore, the Ministry of Trade [3] explains that the role of stakeholder synergy is needed in building the competitiveness of MSMEs through appropriate funding decisions: MSMEs, banking and financial institutions, and the government.

The purpose of this study is to describe the development of the number of MSMEs in Indonesia, describe the number of MSME workforce absorption in Indonesia, describe the number of MSME exports in Indonesia in the period 2010-2018, and find out whether the growth of MSMEs is affected by the growth of the previous period.

\section{Research Methods}

This study used descriptive qualitative method. Secondary data used in this study came from the Ministry of Cooperatives and SMEs in the period 2010-2018 with interval scale and pooled data.

\section{Result and Discussion}

The comparison of Non-Oil and Gas Exports in 2010-2018 is greater in large businesses compared to MSMEs. non-oil exports in large businesses tend to increase, but in MSMEs tend to decrease. Data on non-oil exports at MSMEs and large-scale businesses can be seen in table 1.

Table 1. Non-Oil and Gas Exports of MSMEs and Large Enterprises in 2010-2018

\begin{tabular}{ccc}
\multicolumn{3}{c}{ (in billions of rupiah) } \\
\hline Year & MSMEs & Large Businesses \\
\hline 2010 & $162,254.6$ & $790,835.3$ \\
2011 & $175,894.9$ & $936,825.0$ \\
2012 & $187,441.8$ & $953,009.3$ \\
2013 & $166,626.4$ & $1,018,764.5$ \\
2014 & $182,112.7$ & $979,214.8$ \\
2015 & $185,975.0$ & $996,668.0$ \\
2016 & $255,126.1$ & $1,519,500.8$ \\
2017 & $301,629.9$ & $1,772,195.1$ \\
2018 & $293,840.9$ & $1,750,649.9$ \\
\hline
\end{tabular}

The proportion of MSME non-oil and gas exports compared to large businesses in the 2010-2018 period declined. Various MSME policies that have been carried out such as export facilitation through overseas exhibitions, policies to facilitate export have little impact on MSMEs. Export access is still mostly done by large businesses. 


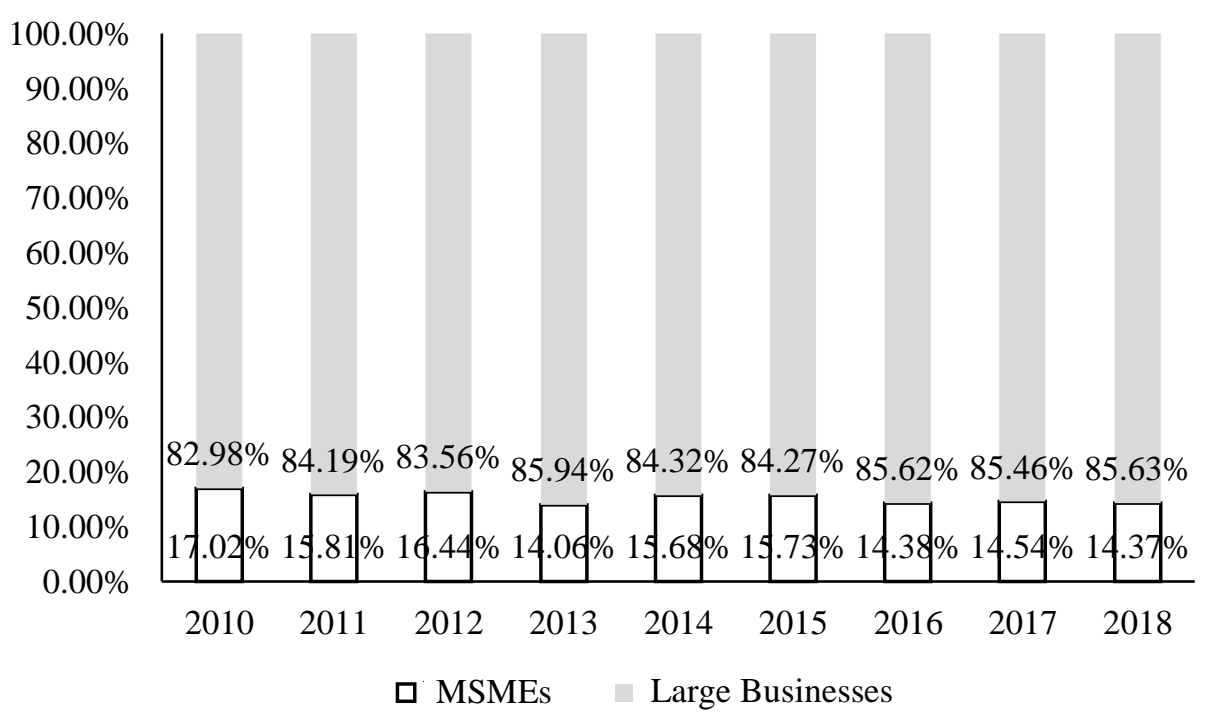

Fig. 1. Non-oil and gas export ratio of MSMEs and large businesses in the 2010-2018 period (in billions of rupiah)

The ability to absorb MSME workers has increased and large businesses have decreased. This indicates that the business climate is conducive for MSMEs. So that many MSMEs increase production capacity and increase labor. However, it can be seen from table 1, that the increase in MSME production capacity is not for export, on the contrary for large businesses to be exported to various countries.

Table 2. Workers working in MSMEs and large businesses in the 2010-2018 period (people)

\begin{tabular}{ccc}
\hline Year & MSMEs & Large Business \\
\hline 2010 & $96,193,623$ & $2,692,374$ \\
2011 & $98,238,913$ & $2,753,049$ \\
2012 & $101,722,458$ & $2,891,224$ \\
2013 & $107,657,510$ & $3,150,645$ \\
2014 & $114,144,082$ & $3,537,162$ \\
2015 & $123,229,387$ & $4,194,051$ \\
2016 & $112,828,610$ & $3,444,746$ \\
2017 & $116,431,224$ & $3,828,953$ \\
2018 & $116,978,631$ & $3,619,507$ \\
\hline
\end{tabular}

The number of MSMEs and large businesses has increased, this is an indication of the ease of licensing the establishment of businesses, obtaining working capital.

Table 3. Number of MSMEs and large business period 2010-2018 (units)

\begin{tabular}{ccc}
\hline Year & MSMEs & Large Business \\
\hline 2010 & $52,764,750$ & 4,676 \\
2011 & $54,114,821$ & 5,150 \\
2012 & $55,206,444$ & 4,952 \\
2013 & $56,534,591$ & 4,968
\end{tabular}




\begin{tabular}{lll}
2014 & $57,895,721$ & 5,066 \\
2015 & $59,262,772$ & 4,987 \\
2016 & $61,651,176$ & 5,370 \\
2017 & $62,922,617$ & 5,460 \\
2018 & $64,194,056$ & 5,550 \\
\hline
\end{tabular}

The number of MSMEs has increased, non-oil exports have fluctuated and the use of labor tends to increase. After 2016, it appears that there is an increase in the use of labor and the number of MSMEs has increased but the products have not been oriented towards exports, so exports tend to decline.

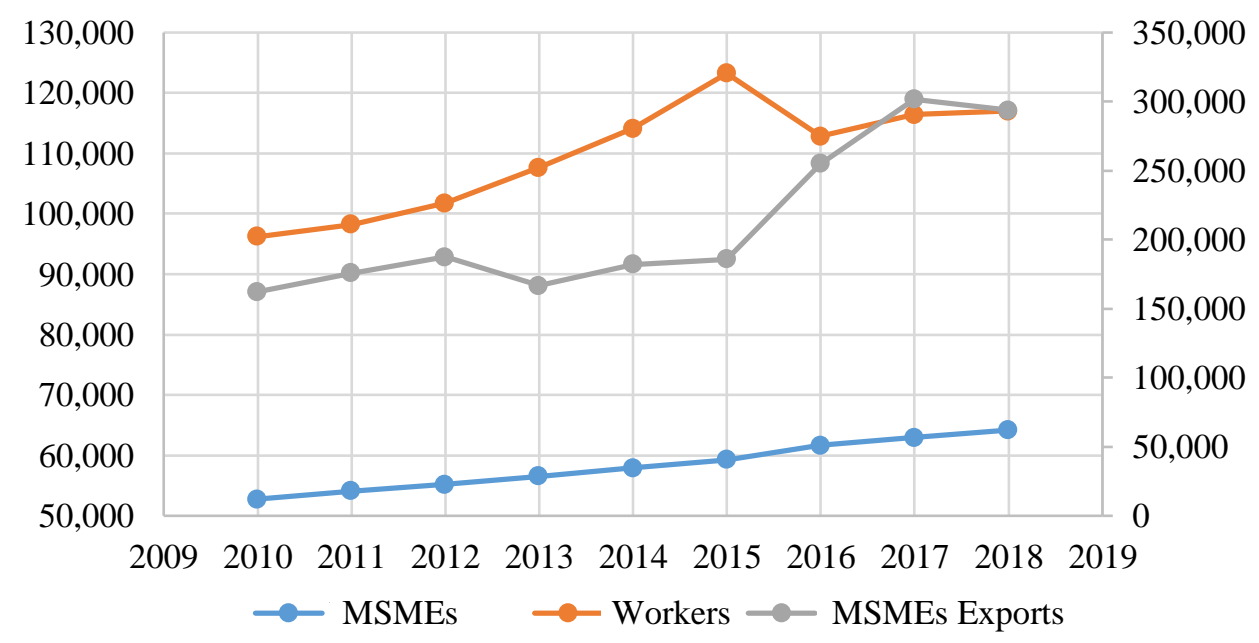

Fig. 2. Number of MSMEs, Use of MSME Workers, MSME Exports for 2010-2018.

\subsection{MSME Growth Prediction}

\subsubsection{Month Moving Average Approach}

Table 4. Moving Average Approach

\begin{tabular}{ccccc}
\hline Year & MSMEs & pred & $|\mathbf{e}|$ & $\mathbf{e}^{\wedge} \mathbf{2}$ \\
\hline 2010 & 52765 & & & \\
2011 & 54115 & & & \\
2012 & 55206 & & & \\
2013 & 56535 & 54028.67 & 2505.919 & 6279631.705 \\
2014 & 57896 & 55285.29 & 2610.436 & 6814374.37 \\
2015 & 59263 & 56545.59 & 2717.187 & 7383103.382 \\
2016 & 61651 & 57897.69 & 3753.481 & 14088622.12 \\
2017 & 62923 & 59603.22 & 3319.394 & 11018376.53 \\
2018 & 64194 & 61278.86 & 2915.201 & 8498396.87 \\
\hline 2019 & & 62922.62 & 62922.62 & 3959255646 \\
2020 & & 63558.34 & 63558.34 & 4039662139 \\
& & & MAE & MSE \\
\cline { 3 - 5 } & & & 18037.82 & 1006625036 \\
\cline { 3 - 5 }
\end{tabular}




\subsubsection{Weighted Moving Average Approach}

Table 5. Weighted Moving Average Approach

\begin{tabular}{|c|c|c|c|c|}
\hline & & & \multicolumn{2}{|c|}{$\mathrm{W}$} \\
\hline & 2010 & & \multicolumn{2}{|c|}{0.1} \\
\hline & 2011 & & \multicolumn{2}{|c|}{0.3} \\
\hline & 2012 & & \multicolumn{2}{|c|}{0.6} \\
\hline & & & \multicolumn{2}{|c|}{1.0} \\
\hline Year & MSMEs & pred & $|\mathrm{e}|$ & $\mathrm{e}^{\wedge} 2$ \\
\hline 2010 & 52765 & & & \\
\hline 2011 & 54115 & & & \\
\hline 2012 & 55206 & & & \\
\hline 2013 & 56535 & 54635 & 1899.8 & 3609252.579 \\
\hline 2014 & 57896 & 55894 & 2001.6 & 4006206.806 \\
\hline 2015 & 59263 & 57218 & 2044.3 & 4179234.859 \\
\hline 2016 & 61651 & 58580 & 3071.3 & 9433113.425 \\
\hline 2017 & 62923 & 60559 & 2363.5 & 5586168.648 \\
\hline 2018 & 64194 & 62175 & 2018.9 & 4075778.741 \\
\hline 2019 & & 63558 & & \\
\hline 2020 & & 25550 & & \\
\hline & & & MAE & MSE \\
\hline & & & 2233.2 & 5148292.509 \\
\hline
\end{tabular}

\subsubsection{ACF (Autocorrelation Function)}

Table 6. Autocorrelation Function

\begin{tabular}{ccccc}
\hline Year & Dow & & Lag & ACF \\
\hline 2010 & 52764.75 & & & \\
2011 & 54114.82 & & 1 & 0.679623 \\
2012 & 55206.44 & & 2 & 0.362767 \\
2013 & 56534.59 & & 3 & 0.049152 \\
2014 & 57895.72 & & 4 & -0.17568 \\
2015 & 59262.77 & & 5 & -0.3408 \\
2016 & 61651.18 & & 6 & -0.43407 \\
2017 & 62922.62 & & 7 & -0.38866 \\
2018 & 64194.06 & & -0.25233 \\
\hline
\end{tabular}

Correlogram

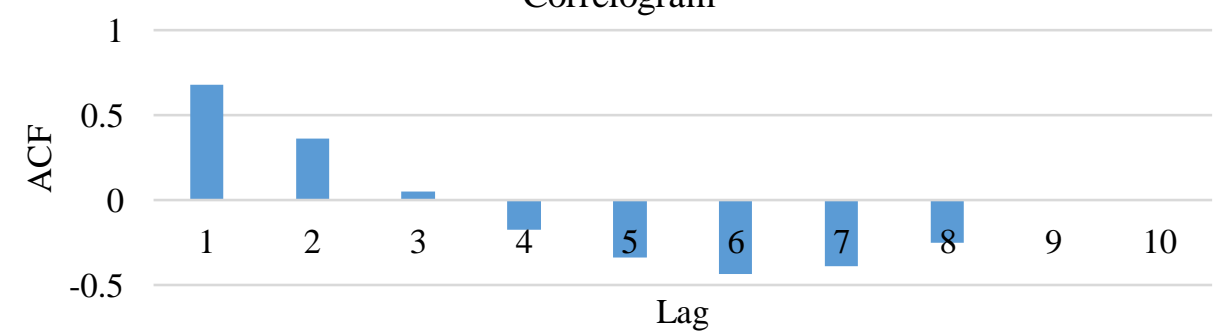




\begin{tabular}{cc}
\hline Bartlett & \\
\hline $\mathrm{n}$ & 9 \\
$\mathrm{~s} . \mathrm{e}$ & 0.333333 \\
alpha & 0.05 \\
crit & 0.653321 \\
$\mathrm{k}$ & 5 \\
$\mathrm{ACF}$ & -0.3408 \\
p-value & 0.846705 \\
sig & no \\
\hline
\end{tabular}

Fig. 3. Correlogram

Based on the data above, it is known that the results are not significant, meaning that there is a growth in the number of MSMEs due to the growth in the number of MSMEs in the next period. Then it can be concluded that the interest in doing business at MSME is determined by the number of MSMEs in the previous period.

\section{Conclusions}

Based on the result above, it can be concluding that the number of MSMEs and the ability to absorb labor has increased from the period 2010-2018. However, the number of non-oil exports have fluctuated from the period 2010-2018. In 2018, on average each MSME is only able to export $0.31 \%$ of total exports. Therefore, MSME facilitation policy from the government is needed so that MSMEs are able to access product sales overseas.

\section{References}

[1] Law No. 20 of 2008 concerning Micro, Small and Medium Enterprises. Jakarta: KKUKM.

[2] N. Riyanto, R. A. Simatupang, and L. S. Bopeng, "Struktur Modal pada usaha mikro kecil dan menengah di kabupaten manokwari," J. Ris. Manaj. dan Bisnis, vol. 11, no. 1, pp. 47-60, 2016.

[3] Kementerian Koperasi dan Usaha Kecil Menengah, "Data UMKM di Indonesia," 2019. [Online]. Available: http://www.depkop.go.id/data-umkm. 